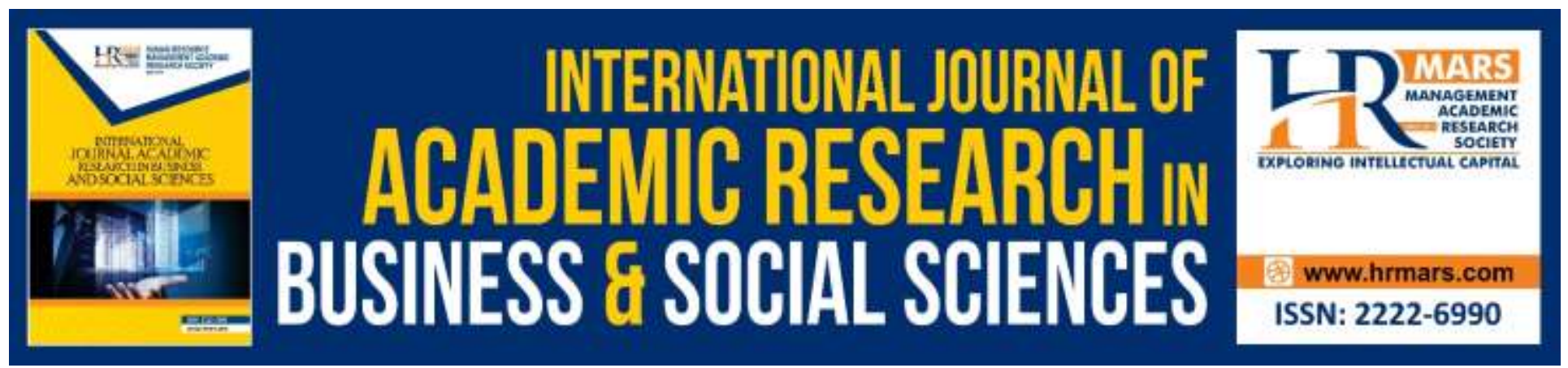

\title{
The Effectiveness of Islamic Education Through Professional Learning Community (PLC) Among Teachers
}

Norfarahin Mohd Zamri, Mohd Isa Hamzah, Shahlan Surat

To Link this Article: http://dx.doi.org/10.6007/IJARBSS/v10-i3/7350

DOI:10.6007/IJARBSS/v10-i3/7350

Received: 26 January 2020, Revised: 29 February 2020, Accepted: 18 March 2020

Published Online: 29 March 2020

In-Text Citation: (Zamri et al., 2020)

To Cite this Article: Zamri, N. M., Hamzah, M. I., \& Surat, S. (2020). The Effectiveness of Islamic Education Through Professional Learning Community (PLC) Among Teachers. International Journal of Academic Research in Business and Social Sciences, 10(3), 902-909.

Copyright: (C) 2020 The Author(s)

Published by Human Resource Management Academic Research Society (www.hrmars.com)

This article is published under the Creative Commons Attribution (CC BY 4.0) license. Anyone may reproduce, distribute, translate and create derivative works of this article (for both commercial and non-commercial purposes), subject to full attribution to the original publication and authors. The full terms of this license may be seen

at: http://creativecommons.org/licences/by/4.0/legalcode

Vol. 10, No. 3, 2020, Pg. 902 - 909

http://hrmars.com/index.php/pages/detail/IJARBSS

JOURNAL HOMEPAGE

Full Terms \& Conditions of access and use can be found at http://hrmars.com/index.php/pages/detail/publication-ethics 


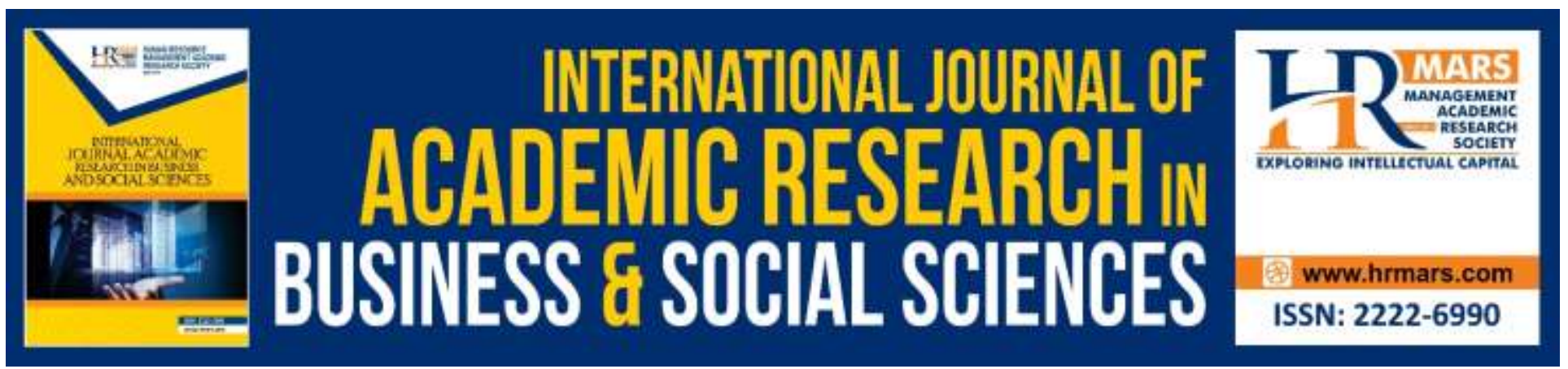

\title{
The Effectiveness of Islamic Education Through Professional Learning Community (PLC) Among Teachers
}

\author{
Norfarahin Mohd Zamri, Mohd Isa Hamzah, Shahlan Surat \\ Faculty of Education, Universiti Kebangsaan Malaysia \\ Email: farahinmohdzamri@gmail.com
}

\begin{abstract}
This paper discusses the effectiveness Islamic Education through Professional Learning Community (PLC) in Malaysia primary schools. In recent years, the Malaysian education system has undergone many changes, such as eliminations of exams in for early primary students in standard one, two and three. The exam-based system has been changed to classroom-based assessment (CBA) to provide an overview of students' performance. This indirectly affects Islamic education, specifically on how to implementing Islamic lesson by teachers. CBA should be carried out during the learning process. To achieve the objective of change, high level of commitment from all teachers is necessary. In Islamic Education, all students will be assessed through their knowledge, skills and value within six level that test the obligatory fardhu ain and fardhu kifayah knowledge in accordance to the students' performance level. Therefore, to meet this challenge, PLC one part of teaching effectiveness appears to achieve this goal.
\end{abstract}

Keywords: Islamic Education, Professional Learning Community, Educational Change.

\section{Introduction}

The main agenda of education in Malaysia is to supply skilled manpower in to achieve the goals of Vision 2020. Teachers play an important role in implementing new policies in education. The main focus of this paper is on teachers' implementing Professional Learning Community (PLC) in school organization to achieve the objective of student performance and strategies for teachers. PLC is a new term amongst teachers' in Malaysia. PLC is one of the practiced strategy in schools, which is a part of the social interaction model (DuFour \& Eaker, 2008). Social interaction models encompass the strategies, which encourage teachers to work collaboratively to reach common goals. These models have evolved over time due to the effort to increase learning involvement in school activities and decision-making experiences and give teachers the chance to interact with teachers from different cultural and socioeconomic backgrounds. Roslizam, Jamilah and Yusof (2018), defined PLC is a collaborative initiative among teachers in a school to enhance teaching and learning quality through 
knowledge and experience sharing to ensure all students would get their right to have fun and effective teaching and learning experience.

This paper aims to examine, first, teacher's knowledge on the professional learning community (PLC), second, teachers' attitude towards the professional learning community, three, teacher's implementation of the Professional Learning Community, fourth, the mean score difference in the level of Islamic Education teacher knowledge on PLC based on their training experience, fifth, the difference between the mean score of Islamic Education teachers' attitude towards PLC based on their training experience and sixth, the difference between the mean score of the level of implementation of PLC for Islamic education based on training experience. In this regard, selecting PLC strategies at school can be used to encourage teacher skills.

\section{Professional Learning Community Model}

PLC have various models created around the year 1990 until 2004 (Sajirah, 2011). Model by Hord (1997a) have been stated by this paper. PLC Model by Hord (1997) is the one of the most popular models among researchers who are measuring the level of PLC Practice. This model produced a questionnaire instrument known as "School Professional Staffs as Learning Communities Questionnaire" (Hord, 2004). This questionnaire is amongst the most stable and strong instruments and has been used by many researchers who are studying the level of PLC practice in educational institutions.

The researchers found that Hord (1997) explained on PLC thoroughly and elaborately and it comprises all aspects that are needed for schools that are practicing it. The five dimensions and 17elements by Hord are comprehensive and include various aspects such as the importance of togetherness in framing and articulating organization goal, the role of school leaders, the importance of leadership sharing quality teaching and learning process accepted by students, sharing of best practices among teachers and support from organization. This model has also been chosen by many local researchers and among them are Hidayah (2014); Marzuki (2013), Norsiah, Azhar and Hassan (2015).

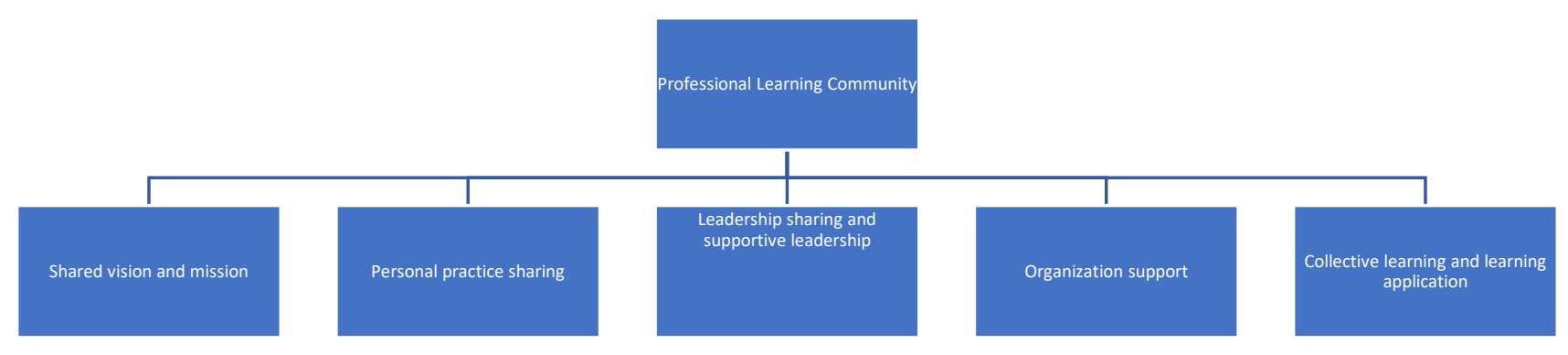

Professional Learning Community Model by Hord (1997a) 


\section{Conceptual Framework}

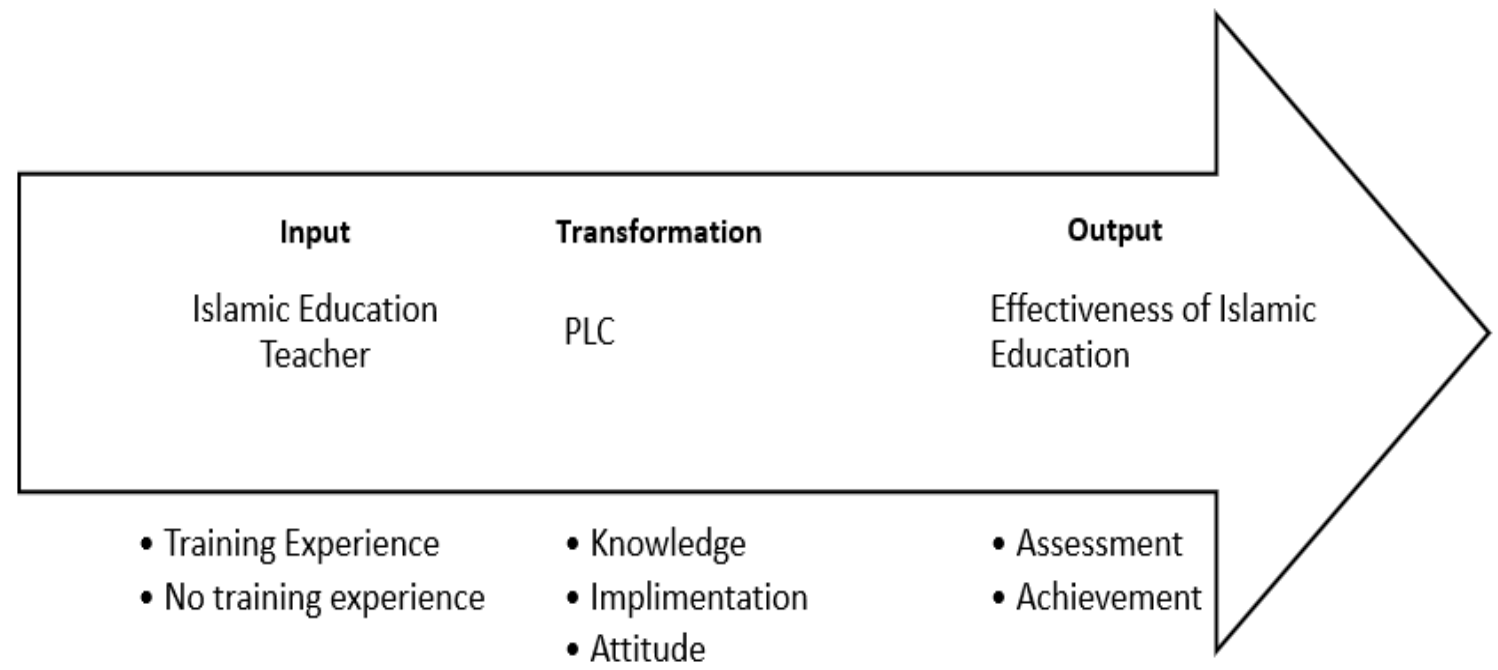

Combinations of Hoy \& Miskel Social Systems Theory (2013), House Goals (2013), \& Public Service Commission Competency Model (2002)

\section{Methodology}

Two municipal zones, Majlis Bandaraya Shah Alam (MBSA) dan Majlis Bandaraya Subang Jaya (MBPJ). The study population consists of Islamic Education teacher. Random sampling was used to obtain a balanced composition of Islamic education teachers in terms of PLC experience. A total of 70 teachers were selected as study sample, consist of 35 teachers who have PLC training experience and 35 teachers who have no PLC training experience. The study used questionnaires to collect data and the questionnaire was adapted from PLC Cultural Level Self-Assessment Questionnaire (2015). The data analysis involves two types of statistics, which are descriptive and inference (t test) to answer the research questions in this study.

\section{Result (S) And Discussion (S)}

The findings of this analysis can be categorized into three aspects, the advantages of implementing PLCs, management of PLC strategies and the relevance of PLCs in Islamic Education.

\section{Teacher Knowledge Levels in the Professional Learning Community}

These findings suggest that the respondents have low knowledge of PLC strategy implementation (mean $=3.60)$, followed by the perception of PLC's suitability in Islamic Education (mean = 3.62), meanwhile, the knowledge of the advantages of implementing PLCs was the highest (mean $=3.70$ ). This indicates that knowledge of the implementation of the PLC strategy needs to be emphasized so that all respondents can implement the PLC properly. The overall level of knowledge shows that all aspects of knowledge are at a moderate level and need to be improved. 
INTERNATIONAL JOURNAL OF ACADEMIC RESEARCH IN BUSINESS AND SOCIAL SCIENCES Vol. 10, No. 3, March, 2020, E-ISSN: 2222-6990 @ 2020 HRMARS

\section{Level of Teacher Attitude towards the Professional Learning Community}

The findings of this analysis cover the aspects of attitude, affective, cognitive and psychomotor. This finding suggests that the aspects that represent the attitude of the respondents towards the PLC are at a moderate level. The lowest aspect $(\min =3.40)$ is the psychomotor aspect of the behavioral tendency, followed by the affective aspect ( $\mathrm{min}=3.44)$. Whereas, the cognitive aspects of knowledge, confidence and trust in PLCs were highest ( $\min =3.57$ ). The overall findings on the level of attitude indicate that all aspects of attitude are at a moderate level and need to be improved. The emphasis on all aspects of attitude, such as the confidence and interest to implement PLC to promote their interest. This is because attitude is an essential element of the belief and opinion (cognitive) that influences positive or negative feelings and determine one's action (psychomotor) (Nor Hannan 2015).

\section{Level of Teacher Implementation of the Professional Learning Community}

The findings showed that the implementation of Lesson Study strategy is the highest among the respondents (mean $=3.20$ ) with 31 respondents $(44.3 \%)$ indicate that they never implemented the strategy. Peer Coaching is the second highest strategy adopted by respondents (mean $=3.04$ ) and 32 (45.7\%) do not implement this strategy. In this light, the majority of respondents have never implemented a strategy other than the focused strategy set by the Petaling Perdana PPD. Only one respondent (1.4\%) strongly agreed that he wants to implement another strategy.

This analysis suggests that most teachers receive support from their respective schools in implementing PLC (mean = 3.23). This is followed by friend support ( $\min =3.11$ ) and school administrator support $(\mathrm{min}=3.09$ ). This shows that the implementation of PLCs in schools is largely driven by the support of PLC coordinators and more support is needed from school administrators to enhance PLC implementation.

Furthermore, the findings indicate that only a small proportion of respondents (mean $=2.94$ ), who are at the lower level, have received support from the school through the PLC. Their understanding of PLCs is at a moderate level ( $\mathrm{min}=3.00)$, which strongly influenced PLC implementation. A total of 31 respondents (44.3\%) disagreed that they have a good understanding of PLC implementation. This suggests that their understanding of PLC is still poor. The overall findings of the implementation level indicate that all aspects are at a moderate level $(\mathrm{min}=3.08)$ and need to be improved through various initiatives.

\section{Mean Score Difference Between Level of Knowledge of Islamic Education Teacher against PLC} Based on Training Experience

Experienced teachers have a higher level of knowledge ( $\min =58.97)$ than inexperienced teachers ( $\min =42.83)$. As this significance level is 0.001 , which is smaller than $0.05(p<0.05)$. Therefore, the null hypothesis (HO1) is rejected. There is a significant difference between the level of knowledge between teachers who have gone through PLC course and those who do not.

\section{Mean Score Difference Between Levels of Attitude of Islamic Education Teachers against PLC Based} on Training Experience

Experienced teachers have better attitude towards PLC (mean $=31.91)$, than inexperienced teachers (mean $=17.31)$. This significance level is 0.001 , which is smaller than $0.05(p<0.05)$. Therefore, the 
INTERNATIONAL JOURNAL OF ACADEMIC RESEARCH IN BUSINESS AND SOCIAL SCIENCES Vol. 10, No. 3, March, 2020, E-ISSN: 2222-6990 @ 2020 HRMARS

null hypothesis ( $\mathrm{HO} 2$ ) is rejected. This reflects a significant difference between the level of attitude between teachers with experience or training and those who do not have any experience.

\section{Difference in Min Score between Level of Implementation of Islamic Education against PLC Based on Training Experience}

The performance level of experienced teachers is higher $(\mathrm{min}=41.51)$ than inexperienced teachers ( $\min =28.09)$. This significance level is 0.001 , which is smaller than $0.05(p<0.05)$. Therefore, the null hypothesis ( $\mathrm{HO} 2)$ is rejected. This indicates a significant difference in the level of implementation between teachers with PLC training experience and those who did not receive any training.

\section{Conclusion (S) And Recommendation (S)}

The results of this study found that the general knowledge on PLC is at a moderate level ( $\min =3.48$ ) while the attitude construct is at the medium level ( $\mathrm{min}=3.64$ ) and the implementation is at the medium level (min $=3.08$ ). It was found that there are significant differences between three constructs, namely the knowledge level, attitude and implementation of the respondents towards the PLC based on course training experience. This study demonstrates the importance of PLC in increasing teachers' knowledge to adapt different methods or strategies in the topic to be taught, especially in the use of methods and exciting planning. This is in line with Khairul Azmi and Ab Halim Tamuri (2007) which state that the use of fun and structured method can affect the students' understanding of the lessons learned.

In the cognitive aspect of trust and confidence there is a high level of attitude. This shows that they are confident that PLC could produce the best possible teaching method, enhancing student learning and achievement as well as creating a fun atmosphere. This is in line with Norhayati (2009) study which found that PLCs are able to provide useful information and knowledge to students in a systematic and efficient manner. Zuraidah (2009) mentioned that most teachers encounter problems in teaching and learning due to the lack of knowledge in determining the approaches, strategies and best teaching practices. Using PLCs can help solve learning problems in line with the PLC goal of producing positive student achievement in diversity (Mohamad, 2005).

Teachers are the catalyst in implementing the PLCs in Islamic Education which act as curriculum implementers. Therefore, teachers need to have knowledge, attitude and implementation of PLCs so that the applications of PLC can have a positive impact. However, the findings of this study show that these three aspects are at a moderate level and need to be upgraded to a higher level. In an effort to enhance the professionalism of teachers as curriculum implementers, the level of knowledge, attitude and implementation are important elements that influence the effectiveness of PLC implementation or any practice in education.

This aspect of knowledge is very important in designing teaching steps to create effective lesson plans and ensure positive impacts on the students. This knowledge can enhance a teacher's ability to apply new strategies in lesson delivery Knowledge is an essential principle to achieve quality. In this regard, teachers need to have a high level of knowledge in all aspects of work to ensure all tasks can be performed well (Mumtaz, 2008).

In the meantime, attitude is an important component for every teacher in terms of pedagogical content and pupils' performance (Zuraidah, 2009). The teacher's positive or negative attitude can affect the students. According to Sani and Izham (2012), knowledge does not guarantee the 
INTERNATIONAL JOURNAL OF ACADEMIC RESEARCH IN BUSINESS AND SOCIAL SCIENCES

Vol. 10, No. 3, March, 2020, E-ISSN: 2222-6990 @ 2020 HRMARS

effectiveness of a curriculum practice because teaching must be implemented in good faith. The combination of positive knowledge and attitude could ensure good practice, particularly in the aspect of PLC implementation. Success of a program is based on the effectiveness of the implementation in line with the goals and goals of education. In this light, Kollmus and Agyemen's (2002) behavioral model states that there is a linear relationship between knowledge, awareness and attitude with behavior.

Therefore, teachers need to pay special attention to the level of readiness in the process of delivering meaningful teaching to the students. Islamic Education teachers need to be given proper exposure to the PLC, so their use can impact teachers and students. This is because teachers' success in communicating the knowledge to the level, appropriateness and variety of pupils will affect their understanding of learning. Teaching practices should be based on systematic knowledge and planning. This is achieved through PLC among the teacher community.

\section{Acknowledgement}

The research was partially supported from the Faculty of Education, Universiti Kebangsaan Malaysia.

\section{Corresponding Author}

Norfarahin Mohd Zamri, Universiti Kebangsaan Malaysia, Email: farahinmohdzamri@gmail.com

\section{References}

DuFour, R., DuFour, R., Eaker, R. (2008). Revisting Professional Learning Communities at Work: New Sight for Improving School. $10^{\text {th }}$ ed. Bloomington, IN: Solution Tree Press, (544)

Roslizam, H., Jamilah, A., \& Yusof, B., (2018). Professional Learning Community in Malaysia. International Journal of Engineering \& Technology, 7(3), 433-443.

Hord, S. M. (1997). Professional Learning Communities: Communities of Continuous Inquiry And Improvement. Austin, Texas: Southwest Educational Development Laboratory, 72.

Hord, S. M. (2004). Learning Together, Leading Together: Changing Schools Through Professional Learning Communities. New York and London: Teachers College Columbia University, 192.

Anja, K., \& Julian, A. (2002). Mind the Gap: Why Do People Act Environmentally and What Are the Barriers to Pro-Environmental Behavior? Enviromental Education Research, 8 (3), 239-260.

DuFour, R. (2004). What Is Professional Learning Community? Educational Leadership, 61(8), 6-11.

Zuraidah, A. (2016). Komuniti Pembelajaran Profesional di Malaysia: Amalan penambahbaikan sekolah. Kuala Lumpur. Penerbit Universiti Malaya. 176.

Marzuki, M. A., Norsiah, A. Z., Azhar. M., Hassan, W. E. W. (2015). Komuniti Pembelajaran profesional: Aplikasi dalam kalangan komuniti SMKA di negeri Johor. International Journal Islam Arabic Language Education, 2(1), 11-22.

Hidayah, H. N. (2014). Hubungan Amalan Komuniti Pembelajaran Profesional Dengan Pencapaian Murid-Murid Sekolah Rendah Daerah Batang Padang. Universiti Pendidikan Sultan Idris.

Zuraidah, A. (2009). Pembentukan Komuniti Pembelajaran Profesional: Kajian Terhadap Sekolah Menengah di Malaysia. Kementerian Pendidikan Malaysia.

Norhayati, A. W. (2009). Amalan-Amalan Komuniti Pembelajaran Profesional Di Sebuah Sekolah Daerah Sepang. Universiti Malaya. 
INTERNATIONAL JOURNAL OF ACADEMIC RESEARCH IN BUSINESS AND SOCIAL SCIENCES

Vol. 10, No. 3, March, 2020, E-ISSN: 2222-6990 @ 2020 HRMARS

Mumtaz, A. K. B. (2008). Learning Organisation: Membentuk Budaya Belajar Dalam Organisasi. Kuala Lumpur: PTS Professional.

Sajirah, I. (2011). Sokongan Pengetua Dalam Amalan Komuniti Pembelajaran Profesional Sebuah Sekolah di Daerah Ledang, Johor. Universiti Malaya.

Mohamad, M. B. (2005). Program Latihan Dalam Perkhidmatan: Pemangkin Perkembangan Profesionalisme Guru. Jurnal Akademik, 1-17.

Sani, I. M., Izham, M. H. M. (2012). Pengurusan Perubahan Peringkat Makro Dalam Pendidikan. Bangi. Universiti Kebangsaan Malaysia. 